International Journal of Linguistics Studies (IJLS)

ISSN: 2754-2599

DOI: $10.32996 / \mathrm{ijls}$

Journal Homepage: www.al-kindipublisher.com/index.php/ijlss

\title{
IJLS
}

\section{Constraints in English Language Teaching and Learning in Senior Secondary Schools: Strategies for Implementation}

\author{
Steven Sylvester Bockarie ${ }^{1} \square$ and Michael Sahr Bengu ${ }^{2}$ \\ ${ }^{1}$ Language Studies Department, Faculty of Education, Eastern Technical University Sierra Loene, West Africa \\ ${ }^{2}$ Language Education Unit, Faculty of Education, Earnest Bai Koroma University of Science and Technology, Sierra Leone, West \\ Africa
}

$\square$ Corresponding Author: Steven Sylvester Bockarie, E-mail: bockariesteven@yahoo.com

\begin{tabular}{ll}
\hline ARTICLE INFORMATION & ABSTRACT \\
\hline
\end{tabular}

Received: 02 November 2021

Accepted: 29 November 2021

Published: 31 December 2021

DOI: $10.32996 /$ ijls.2021.1.2.10

\section{KEYWORDS}

Constraints, strategies for implementation, senior secondary school, English language, Sierra Leone
The study entitled 'Constraints in English Language Teaching and Learning in Senior Secondary Schools: Strategies for Implementation' seeks to unravel the myriad of problems in teaching and learning the English Language in senior secondary schools and offers strategies that can be implemented to salvage the situation. Learning to teach is more than simply knowing the results of research and theory; it always involves learning the 'craft' of classroom exposition, explanation, organization, and guidance. The desired outcome of the language learning process is the ability to communicate competently, not the ability to the ability to use the language exactly as a native speaker does. To guide the study, three research questions were posed. The questions examined the following three variables: (1) the constraints in teaching English; (2) the constraints in learning English; and (3) strategies for implementation in senior secondary schools. The research will be carried out in two senior secondary schools in Kenema City, Eastern Sierra Leone (Government Senior Secondary School and Methodist Senior Secondary School). The study revealed that: the lack of adequate teaching and learning materials, poor pedagogical and academic subject matter competency, and the negative attitude of students towards the English Language, account for the major constraints in the teaching and learning of the subject.

\section{Introduction}

The importance of English Language teaching and learning as a stepping stone for proficiency in other school subjects cannot be overemphasized. Some of the prominent constraints that have stymied the efforts of teachers and learners in the Sierra Leonean secondary schools at achieving competence in the English Language include; Mother Tongue Interference: According to Awoniyi (1978), mother tongue is defined as the Language which a group of people considered to be inhabitants of an area acquired in the early years and which eventually becomes their natural instruments of thought and communication. In simplistic terms, mother tongue can be expressly defined as the Language the child is first exposed to irrespective of the Language of the parents.

Drawing from this viewpoint, the person is defined as a native speaker of the first Language, although one may also be a native speaker of more than one Language if all of the languages were learned without formal education.

The species of constraints has almost invariably constituted problems to both teachers and learners in their grim determination to develop a sound grasp of the English Language.

It is unfortunate that most school leavers do not possess the required English Language competence skill for both cognitive and communicative functions.

Statistics released by the West African Examination Council (WAEC), which conducts the West African Senior Secondary Certificate Examination, indicates that less than ten percent of secondary school leavers pass English at Credit Level. At the tertiary level of

Copyright: (C) 2021 the Author(s). This article is an open access article distributed under the terms and conditions of the Creative Commons Attribution (CC-BY) 4.0 license (https://creativecommons.org/licenses/by/4.0/). Published by Al-Kindi Centre for Research and Development, London, United Kingdom. 
education, students have so much difficulty with their communicative skills in English that they cannot function effectively in the academic use of English.

The teaching and learning of the English Language are abysmal due to the mother tongue constraint, which has in every possible assessment engendered a staggering and persistent decline in the quality of Language taught and spoken in most secondary schools.

The pedagogical approach, therefore, should incorporate the teaching and learning of the four language skills of Listening, Speaking, Reading and Writing forces in the realization of the aims and objectives of teaching the English Language in secondary schools.

In spite of these varying approaches used in the teaching and learning of the English Language, the intended purposes are far from being realized in most secondary schools.

As a result, there are growing concerns over the poor performance of pupils over the years. This has been attributed to several factors amidst varying points of view.

Therefore, this study seeks to investigate the constraints in English Language teaching and learning in secondary schools and highlight some strategies that can be implemented to remedy the constraints. A case study has been made to two secondary schools, including both teachers and pupils in Kenema City, Eastern Sierra.

\subsection{Statement of Problem}

The majority of the pupils in secondary schools in Sierra Leone have no ample opportunity to study English Language anymore except those who wish to study English and related subjects such as Linguistics and Literature later in College.

In order to study English as a second language and be successful at it, the pupil must be helped by the teacher to acquire skills in the four language arts skills, namely: speaking, reading, listening and writing.

\subsection{Purpose of Study}

This study aims to investigate the constraints in English Language teaching and learning in senior secondary schools and offer strategies for implementation.

\section{Review of Literature}

Although many people would agree that there is an observable fall in the standard of education in Sierra Leone, nobody, in his or her widest sense of imagination, would have believed that Senior Secondary School education in Sierra Leone would fall to such an abysmally low level. At the Senior Secondary School level, the student is given adequate knowledge and skills in the use of English. A mastery of both the written and spoken aspects of the Language is highly desirable, yet its teaching and learning are beset by a host of problems at the Senior Secondary School level.

According to Wendy et al. (1990), the ultimate aim of all English teaching is for students to know English or at least to know English enough for whatever purpose they have in learning the Language.

The teacher should be aware of what are the aspects of the Language that need to be learnt. Lisbeth (1990) observed that students need to develop skills in listening, speaking, reading and writing; how much attention is paid to each skill will depend on the students' needs and interests. The teacher who teaches English would develop practical skills in teaching the subject as a second language.

The works of Wendy A. Scott et al. (1990), claimed that teachers teaching English as a second language have a lot to do. They should be aware that words are not enough. They should include activities in their lessons, and they should use Language frequently. Spoken words are to be accompanied by other clues to meaning alongside facial expressions and movement.

They should use variety in the classroom: the variety of activities, organization and voice. They should also organize and plan their lessons. They should bear in mind that learning is cooperation and not competition.

In line with the works of Doff Adrain (1988), a traditional approach to learning is learning by heart, and many people still attempt to learn languages by learning sentences through dialogues and by heart. Adrian (1988) observed that learning by heart is likely to be most useful in learning fixed and limited things. It is often found to be a useful way of mastering certain fixed items in a language, such as numerals or irregular past tense forms. Adrian, however, argued that the problem with learning by heart as a strategy for learning the whole of a language is not something that is limited and infinite; it is not a body of knowledge but a set of skills. Adrian went on to state that learning a language must mean learning to use those skills. 
According to Crystal (1987), the most obvious way of reducing some of the powers of the language barrier is to promote the teaching and learning of foreign languages in a variety of child and adult educational settings. According to him, this widely practised approach is undoubtedly proving to be successful, as can be judged by the millions who succeed in mastering a foreign language. Crystal also explained that there is also a great deal of educational failure and lack of achievement in the language learning field. Although many have tried to learn a foreign language (like English), they have made little progress in it.

"It is therefore important to study the factors that govern success or failure in this field."

Crystal further highlights some of the factors that govern success or failure in the teaching and learning of English as a foreign language.

This he said includes:

- The soundness of the teaching method

- $\quad$ The attitude and motivation of the learner

- The availability of the time and opportunities to learn

- $\quad$ The chance to put the Language to active use.

Crystal further explains the concept of the teaching and learning of English as a foreign language. According to him, the concept of 'foreign language teaching (FLT)' and 'foreign language learning' (FLL) reflect an important development in the modern study of the subject. In his view, foreign language teaching was thought at one time to be exclusively a matter of teaching techniques; it was felt that if teaching was above a certain level of efficiency, learning would automatically follow. Teaching, according to him, was the active skill while learning the passive one. Crystal added that the role of learners today is an established principle.

Research is therefore now directed not only at the way teachers teach but also at the way learners learn (Crystal 1987: 368)

Norton et al. (1980) emphasized that the teacher of English should be adequately trained to be able to motivate learners to use correct grammatical structures to construct sentences. Other practical problems such as poor working conditions, the absence of inducement for teachers, lack of effective supervision of teachers of English, and overcrowded classrooms all militate against the effective teaching and learning of English. Norton further suggests that supplementary reading materials, language room, library, tape recorders, and other teaching aids are necessary for the pupils learning of English.

According to Barr et al. (2012), there are some recommended strategies and types of instruction teachers should keep in mind in order to promote the teaching and learning of English in Senior Secondary Schools. These include literature appreciation, direct teaching of decoding, phonemic awareness instruction in the code system of written English, vocabulary instruction, word structure origin, relationship among words, comprehension strategies such as prediction, summarizing, clarifying, questions, and regular exposure to many types of text.

Freeborn et al. (1991) assert that the range of situations in which Language is used, the many kinds of people with whom we communicate, and the different purposes for which we talk or write, the task of describing all the varieties of English usage proves very daunting.

Freeborn further draws an analogy of the English Language as a system that we have all learnt and carry around in our minds.

According to him, whenever we talk or write, we have to make choices from their system, which gives us a number of alternatives at each linguistic level, including choice of words from our vocabulary and different ways of putting together these words in a string called sentences. As he puts it:

Our sentences must obey the rules which everyone who speaks or writes English follows, our vocabulary and grammar must be in the right style or appropriate to the context, as well as grammatically correct, the words must be in the right order, in order to be grammatical, but again there is enough flexibility to allow a lot of choices (Freeborn 1991: 126)

In his view, vocabulary development proves to be essential for learners of English. This, to a large extent, help them make a varying choice of words in specific context and situations and that, construction of good sentences (written or spoken) depends largely on the learners choice of words.

It is worthy to note that the unsatisfactory performance of students in reading and comprehension, continuous writing and oral English has to do with the student limited vocabulary choice. Some of them find it extremely difficult to read and understand comprehension passages, especially where they come across strange and difficult words. 


\section{Methodology}

\subsection{Study Area}

This research was carried out in two secondary schools. They are the Government Senior Secondary School and the Methodist Senior Secondary School in Kenema. They are both located in Kenema City, Eastern Sierra Leone.

\subsection{Population and Sample}

The research was carried out using English Language teachers and the students at the Senior Secondary School level in the two target Schools.

\subsection{Sample and Sampling Technique}

One hundred and forty students were selected: seventy students per school. Five (5) teachers were selected from each Secondary School.

\subsection{Instruments for Data Collection}

Two sets of structured questionnaires were designed for the research. One set of questionnaires was prepared for the students and another set for the teachers.

\subsection{Method of Data Collection}

The researchers used well-structured questionnaires, focus group discussions, informal interviews and personal experience to collect the required data.

\section{Presentation of results and discussions}

Data obtained from the respondents are presented in tabular forms as follows:

Table 1. Pupils who use English in School

\begin{tabular}{|l|l|l|l|l|}
\hline & \multicolumn{2}{|l|}{$\begin{array}{l}\text { GOVERNMENT } \\
\text { SCHOOL }\end{array}$} & SECONDARY & \multicolumn{2}{l|}{$\begin{array}{l}\text { METHODIST SENIOR } \\
\text { SECONDARY SCHOOL }\end{array}$} \\
\hline Sex & No. & $\%$ & No. & $\%$ \\
\hline Very Often & 10 & 14 & 05 & 7 \\
\hline Often & 12 & 17 & 06 & 9 \\
\hline Seldom & 30 & 43 & 42 & 60 \\
\hline Very Seldom & 18 & 26 & 17 & 24 \\
\hline TOTAL & $\mathbf{7 0}$ & $\mathbf{1 0 0}$ & $\mathbf{7 0}$ & $\mathbf{1 0 0}$ \\
\hline
\end{tabular}

According to table one, $14 \%$ of students of the Government Secondary School Kenema speak English very often. Also, $17 \%$ and 9\% of students speak English at the Government secondary school and the Methodist Senior Secondary School, respectively. The table further explains that $43 \%$ of students at the Government Senior Secondary School Kenema and $60 \%$ of students at the Methodists Senior Secondary School, Kenema speak English seldom. And finally, according to table one, $26 \%$ of students speak English very seldom at the Methodist Senior Secondary School, and 24\% speak English very seldom at the Government Senior Secondary School, Kenema. The result reveals that there are a greater number of students in both institutions who either speak English seldom or very seldom. This indicates that students very often speak other languages apart from English. This could be a contributing factor for students' lack of fluency in English since everybody becomes fluent by speaking.

Table 2: Teaching English Language Lessons

\begin{tabular}{|l|l|l|l|l|l|}
\hline \multicolumn{2}{|l|}{ METHODIST SECONDARY SCHOOL } & \multicolumn{3}{|l|}{$\begin{array}{l}\text { GOVERNMENT } \\
\text { SECONDARY SCHOOL }\end{array}$} \\
\hline & No. & $\%$ & No. & $\%$ \\
\hline $\begin{array}{l}\text { The teacher gives explanations that } \\
\text { are clear and to the point }\end{array}$ & 66 & 94 & 65 & 93 \\
\hline $\begin{array}{l}\text { The teacher wastes a lot of time } \\
\text { talking about unrelated issues }\end{array}$ & 04 & 6 & 05 & 7 \\
\hline $\begin{array}{l}\text { The teacher teaches things not } \\
\text { related to the topic. }\end{array}$ & - & - & - & - \\
\hline TOTAL & $\mathbf{7 0}$ & $\mathbf{1 0 0}$ & $\mathbf{7}$ & $\mathbf{1 0 0}$ \\
\hline
\end{tabular}


According to table two, $94 \%$ of student respondents at the Methodist Secondary School indicated that their teachers give explanations that are clear and to the point, while $93 \%$ of students respondents indicated the same at the Government Secondary School Kenema.

At the Methodist Secondary School, 6\% pointed out that teachers waste a lot of time talking about unrelated issues in the classrooms; and 7\% at the Government Secondary School pointed out on the same note. On the issues of teachers teaching things not related to the topic, all student respondents from both institutions indicated the non-occurrences of such situations.

Table 3: Love of English Language as a Subject.

\begin{tabular}{|l|l|l|l|l|}
\hline & $\begin{array}{l}\text { GOVERNMENT } \\
\text { SCHOOL }\end{array}$ & SECONDARY & $\begin{array}{l}\text { METHODIST } \\
\text { SCHOOL }\end{array}$ & SECONDARY \\
& No. & $\%$ & No. & $\%$ \\
\hline Yes & 50 & 71 & 46 & 66 \\
\hline No & 20 & 29 & 24 & 34 \\
\hline TOTAL & $\mathbf{7 0}$ & $\mathbf{1 0 0}$ & $\mathbf{7 0}$ & $\mathbf{1 0 0}$ \\
\hline
\end{tabular}

From the above table, $71 \%$ and $66 \%$ of student respondents from the Government secondary school and the Methodist Secondary School respectively agreed that they like the English Language as a subject generally. And 29\% of respondents at the Government Secondary School showed that they do not like the English Language, while $34 \%$ of student respondents at the Methodist Secondary School indicated the same view.

Table 4: Teachers have Adequate Knowledge in their Subject

\begin{tabular}{|c|c|c|c|c|}
\hline & \multicolumn{2}{|c|}{$\begin{array}{l}\text { METHODIST } \\
\text { SECONDARY SCHOOL }\end{array}$} & \multicolumn{2}{|c|}{$\begin{array}{l}\text { GOVERNMENT SECONDARY } \\
\text { SCHOOL }\end{array}$} \\
\hline & No. & $\%$ & No. & $\%$ \\
\hline Strongly agree & 52 & 74 & 40 & 57 \\
\hline Agree & 14 & 20 & 25 & 36 \\
\hline Disagree & 04 & 6 & 05 & 7 \\
\hline Strongly disagree & - & - & - & - \\
\hline TOTAL & 70 & 100 & 70 & 100 \\
\hline
\end{tabular}

According to the table, $74 \%$ of students at the Methodist Secondary School and $57 \%$ at the Government Secondary School, Kenema, strongly agreed that their English Language teachers have adequate knowledge in their subject area.

Also, $20 \%$ at the Methodist and $36 \%$ at the Government Secondary School agreed that their English Language teachers have adequate knowledge in their subject area. The table further shows that $6 \%$ and $7 \%$ of students at the Methodist Secondary School and the Government Secondary School disagreed that their English Language teachers have adequate knowledge of their subject matter.

The result here shows that in spite of students' poor performance in the English language, their teachers have adequate knowledge in their subject areas, as shown in table four.

Table 5: Teachers Have Adequate Motivating Skills in Teaching English Language

\begin{tabular}{|c|c|c|c|c|c|}
\hline & \multicolumn{2}{|c|}{$\begin{array}{l}\text { METHODIST } \\
\text { SECONDARY } \\
\text { SCHOOL }\end{array}$} & \multicolumn{3}{|c|}{$\begin{array}{l}\text { GOVERNMENT SECONDARY } \\
\text { SCHOOL }\end{array}$} \\
\hline & No. & $\%$ & No. & $\%$ & \\
\hline Strongly Agree & 17 & 24 & 18 & 26 & \\
\hline Agree & 45 & 64 & 42 & 60 & \\
\hline Disagree & 08 & 12 & 10 & 14 & \\
\hline Strongly Disagree & - & - & - & & - \\
\hline TOTAL & 70 & 100 & 70 & 100 & \\
\hline
\end{tabular}

The table indicates that $24 \%$ at the Methodist Secondary School and $26 \%$ at the Government Secondary School strongly agreed that their teachers have adequate motivating skills in teaching the English language. It is also indicated by $64 \%$ and $46 \%$ of students 
who agreed that their teachers have adequate motivating skills in teaching the English Language at the Methodist Secondary School and the Government Secondary School, respectively.

However, $12 \%$ and $14 \%$ of students disagreed that teachers have adequate motivating skills to teach the English Language at the Methodist Secondary School and the Government Secondary School. According to table five, the result reveals that teachers have adequate motivating skills in teaching the English Language, although a smaller percentage disagreed.

Table 6: Oral English is not usually taught

\begin{tabular}{|l|l|l|l|l|}
\hline & \multicolumn{2}{|l}{$\begin{array}{l}\text { METHODIST SECONDARY } \\
\text { SCHOOL }\end{array}$} & \multicolumn{2}{l|}{$\begin{array}{l}\text { GOVERNMENT SECONDARY } \\
\text { SCHOOL }\end{array}$} \\
\hline & No. & $\%$ & No. & $\%$ \\
\hline Strongly Agree & 30 & 43 & 08 & 11 \\
\hline Agree & 38 & 54 & 47 & 67 \\
\hline Disagree & 02 & 3 & 13 & 19 \\
\hline Strongly Disagree & \multicolumn{1}{|c|}{-} & - & - & - \\
\hline TOTAL & $\mathbf{7 0}$ & $\mathbf{1 0 0}$ & $\mathbf{7 0}$ & $\mathbf{1 0 0}$ \\
\hline
\end{tabular}

According to the table, $43 \%$ of students and $11 \%$ of students at the Methodist Secondary School and the Government Secondary School respectively strongly agreed that Oral English is not usually taught in their schools. Also, $54 \%$ of students at the Methodist Secondary School and $67 \%$ of students at the Government Secondary School agreed. Moreover, at the Methodist Secondary School, $3 \%$ of students $19 \%$ of students at the Government Secondary School disagreed.

The result of the study, according to the table, reveals that oral English is not usually taught by teachers in those institutions.

Table 7: Debating Societies in School.

\begin{tabular}{|l|l|l|l|ll|}
\hline & $\begin{array}{l}\text { METHODIST } \\
\text { SCHOOL }\end{array}$ & \multicolumn{2}{l|}{ SECONDARY } & \multicolumn{2}{l|}{$\begin{array}{l}\text { GOVERNMENT SECONDARY } \\
\text { SCHOOL }\end{array}$} \\
\hline & No. & $\%$ & No. & $\%$ & \\
\hline Yes & - & - & - & \multicolumn{2}{l|}{100} \\
\hline No & 70 & 100 & 70 & - & \\
\hline TOTAL & $\mathbf{7 0}$ & $\mathbf{1 0 0}$ & $\mathbf{7 0}$ & $\mathbf{1 0 0}$ & \\
\hline
\end{tabular}

According to the table, $100 \%$ of the Government Secondary School students confirmed that their school has a debating society. The table further shows that the Methodist Secondary School does not have a debating society. The result here reveals that even though the Government Secondary School has a literary and debating society, students still exhibit poor English language performance.

Table 8: Listening to English Radio Programmes

\begin{tabular}{|c|c|c|c|c|}
\hline & \multicolumn{2}{|c|}{$\begin{array}{l}\text { METHODIST } \\
\text { SCHOOL }\end{array}$} & \multicolumn{2}{|c|}{$\begin{array}{l}\text { GOVERNMENT SECONDARY } \\
\text { SCHOOL }\end{array}$} \\
\hline & No. & $\%$ & No. & $\%$ \\
\hline Yes & 05 & 8 & 10 & 4 \\
\hline No & 65 & 93 & 60 & 86 \\
\hline TOTAL & 70 & 100 & 70 & 100 \\
\hline
\end{tabular}

According to the table, $8 \%$ of students of the Methodist Secondary School listen to English radio programmes, while $14 \%$ of students at the Government Secondary School Kenema listen to English radio programmes. On the other hand, $93 \%$ of students and $86 \%$ of students at the Methodist Secondary School and the Government Secondary School respectively do not listen to any English radio programmes. The result of the study indicates that a greater percentage of students do not listen to English radio programmes. This limited exposure to the Language hampers effective teaching and learning. 
Tables 9: Learning Materials used

\begin{tabular}{|l|l|l|l|l|}
\hline & \multicolumn{3}{|l|}{$\begin{array}{l}\text { METHODIST SECONDARY } \\
\text { SCHOOL }\end{array}$} & $\begin{array}{l}\text { GOVERNMENT } \\
\text { SCHOOL }\end{array}$ \\
\hline & No. & $\%$ & No. & $\%$ \\
\hline Textbooks & 11 & 16 & 31 & 44 \\
\hline Pamphlets & 59 & 84 & 39 & 56 \\
\hline TOTAL & $\mathbf{7 0}$ & $\mathbf{1 0 0}$ & $\mathbf{7 0}$ & $\mathbf{1 0 0}$ \\
\hline
\end{tabular}

The table reveals that at the Methodist Secondary School, $16 \%$ of students and $44 \%$ of students at the Government Secondary School reported that textbooks are used in teaching the English Language. Also, $84 \%$ of students at the Methodist Secondary School and $6 \%$ of students at the Government Secondary School reported that pamphlets are the most often used materials in the teaching and learning of the English Language. The result, therefore, shows that pamphlets or handouts are the most often used materials in English language teaching and learning.

Table 10: Availability of Internet Facility.

\begin{tabular}{|l|l|l|l|l|}
\hline & \multicolumn{2}{|l|}{$\begin{array}{l}\text { METHODIST } \\
\text { SECONDARY SCHOOL }\end{array}$} & $\begin{array}{l}\text { GOVERNMENT } \\
\text { SCHOOL }\end{array}$ \\
\hline & No. & $\%$ & No. & $\%$ \\
\hline Yes & - & - & - & - \\
\hline No & 70 & 100 & 70 & 100 \\
\hline TOTAL & $\mathbf{7 0}$ & $\mathbf{1 0 0}$ & $\mathbf{7 0}$ & $\mathbf{1 0 0}$ \\
\hline
\end{tabular}

According to the result of the finding, $100 \%$ of students at the Methodist secondary and $100 \%$ at The Government Secondary School, Kenema responded that their institutions do not have internet for public use.

Table 11: Assigning of Group/Pair work to students.

\begin{tabular}{|l|l|l|l|l|}
\hline & \multicolumn{2}{|l|}{$\begin{array}{l}\text { METHODIST } \\
\text { SECONDARY SCHOOL }\end{array}$} & \multicolumn{2}{l|}{ GOVERNMENT SECONDARY SCHOOL } \\
\hline & No. & $\%$ & No. & $\%$ \\
\hline Yes & - & - & - & - \\
\hline No & 70 & 100 & 70 & 100 \\
\hline TOTAL & $\mathbf{7 0}$ & $\mathbf{1 0 0}$ & $\mathbf{7 0}$ & $\mathbf{1 0 0}$ \\
\hline
\end{tabular}

The above table indicates an overwhelming response in relation to teachers' attitudes to group/pair work in the classroom. The result indicates that teachers in both schools do not use pair/group work in the teaching and learning of the English Language.

Table 12: Teachers' training in English Language Teaching Pedagogy.

\begin{tabular}{|l|l|l|l|l|}
\hline & \multicolumn{2}{|l|}{$\begin{array}{l}\text { METHODIST } \\
\text { SECONDARY SCHOOL }\end{array}$} & $\begin{array}{l}\text { GOVERNMENT } \\
\text { SCHOOL }\end{array}$ \\
\hline & No & $\%$ & No & $\%$ \\
\hline Yes & 01 & 20 & 01 & 20 \\
\hline No & 04 & 80 & 04 & 80 \\
\hline TOTAL & $\mathbf{0 5}$ & $\mathbf{1 0 0}$ & $\mathbf{0 5}$ & $\mathbf{1 0 0}$ \\
\hline
\end{tabular}

According to the table, $20 \%$ of staff respondents and $20 \%$ of staff respondents at the Methodist Secondary School and the Government Secondary School respectively have attended in-service training on English Language teaching methodology. The result further shows that $80 \%$ of staff respondents at the Methodist Secondary School and $80 \%$ of staff respondents at the Government Secondary School have not attended any in-service training on language pedagogy. The result here indicates that a good number of English Language teachers in both institutions have not undergone any in-service training in the English Language. 
Table 13: Students do not Attend English Language Classes Regularly

\begin{tabular}{|l|l|l|l|l|}
\hline & \multicolumn{2}{|l|}{ METHODIST SECONDARY SCHOOL } & \multicolumn{2}{l|}{$\begin{array}{l}\text { GOVERNMENT } \\
\text { SECONDARY SCHOOL }\end{array}$} \\
\hline & No & $\%$ & No & $\%$ \\
\hline Strongly Agree & 01 & 20 & - & - \\
\hline Agree & 01 & 20 & 04 & 80 \\
\hline Disagree & 03 & 60 & 01 & 20 \\
\hline Strongly Disagree & & - & & - \\
\hline TOTAL & $\mathbf{0 5}$ & $\mathbf{1 0 0}$ & $\mathbf{0 5}$ & $\mathbf{1 0 0}$ \\
\hline
\end{tabular}

According to the table, $20 \%$ of respondents at the Methodist Secondary School strongly agreed that students do not attend English Language lessons regularly, while $20 \%$ of respondents and $80 \%$ of the respondents at the Methodist Secondary School and the Government Secondary School respectively agreed. The result further revealed $60 \%$ at the Methodist Secondary School, and $20 \%$ at the Government Secondary School disagreed. The result shows that students in both institutions do not attend English Language classes regularly.

Table 14: The Administration Fully Supports Both Students and Staff in the Teaching/Learning of English Language.

\begin{tabular}{|c|c|c|c|c|c|}
\hline & \multicolumn{2}{|c|}{$\begin{array}{l}\text { METHODIST } \\
\text { SECONDARY SCHOOL }\end{array}$} & \multicolumn{2}{|c|}{$\begin{array}{l}\text { GOVERNMENT } \\
\text { SCHOOL }\end{array}$} & SECONDARY \\
\hline & No & $\%$ & No & $\%$ & \\
\hline Strongly Agree & - & - & - & & \\
\hline Agree & 03 & 60 & 02 & 40 & \\
\hline Disagree & 02 & 40 & 03 & 60 & \\
\hline Strongly Disagree & - & - & - & & \\
\hline TOTAL & 05 & 100 & 05 & 100 & \\
\hline
\end{tabular}

The table indicates that $60 \%$ of staff respondents at the Methodist Secondary School agreed that they enjoy full support from the administration in the teaching/learning of the English Language, while $40 \%$ of staff respondents at the Government Secondary School agreed. On the other hand, $40 \%$ of staff respondents and $60 \%$ of staff respondents at the Methodist Secondary School respectively disagreed.

Table 15: Components of English Language Students Find Most Difficult.

\begin{tabular}{|c|c|c|c|c|}
\hline \multicolumn{3}{|c|}{ METHODIST SECONDARY SCHOOL } & \multicolumn{2}{|c|}{$\begin{array}{l}\text { GOVERNMENT } \\
\text { SECONDARY SCHOOL }\end{array}$} \\
\hline & No. & $\%$ & No. & $\%$ \\
\hline Grammar & 2 & 40 & 02 & 40 \\
\hline Essay Writing & 01 & 20 & 02 & 40 \\
\hline Comprehension and Summary & 02 & 40 & 01 & 20 \\
\hline Oral Writing & - & - & - & - \\
\hline TOTAL & 05 & 100 & 05 & 100 \\
\hline
\end{tabular}

According to the table, $40 \%$ of staff respondents from the Methodist Secondary School and $40 \%$ of staff respondents at the Government Secondary School reported that Grammar is the aspect their students find most difficult. Also, 20\% of staff respondents and $40 \%$ of staff respondents at the Methodist Secondary School and the Government Secondary School, respectively, find Essay writing the most difficult. The table further shows that $40 \%$ of staff respondents at the Methodist Secondary School and $20 \%$ of staff respondents at the Government Secondary School find Comprehension and Summary most difficult for their students.

The result of the study reveals that in both schools, students find Grammar, Essay writing and Comprehension and Summary most difficult as aspects of the English language. 
Table 16: Availability of Language Lab for the Teaching of Oral English.

\begin{tabular}{|l|l|l|l|l|}
\hline & \multicolumn{1}{|c|}{$\begin{array}{l}\text { METHODIST } \\
\text { SCHOOL }\end{array}$} & \multicolumn{1}{|c|}{ SECONDARY } & $\begin{array}{l}\text { GOVERNMENT } \\
\text { SECONDARY SCHOOL }\end{array}$ \\
\hline & No & $\%$ & No & $\%$ \\
\hline Yes & - & - & - & - \\
\hline No & 05 & 100 & 05 & 100 \\
\hline TOTAL & $\mathbf{0 5}$ & $\mathbf{1 0 0}$ & $\mathbf{0 5}$ & $\mathbf{1 0 0}$ \\
\hline
\end{tabular}

The above table indicates that there is no language lab at the Methodist Secondary School, and the same situation holds the same for the Government Secondary School. This may be responsible for teachers' lack of interest in teaching oral English in Secondary Schools.

Table 17: Teaching Load per Week.

\begin{tabular}{|l|l|l|l|l|}
\hline & \multicolumn{2}{|l|}{$\begin{array}{l}\text { METHODIST SECONDARY } \\
\text { SCHOOL }\end{array}$} & $\begin{array}{l}\text { GOVERNMENT SECONDARY } \\
\text { SCHOOL }\end{array}$ \\
\hline & No & $\%$ & No & $\%$ \\
\hline $4-6$ Period & 01 & 20 & 02 & 40 \\
\hline $7-9$ Period & 02 & 40 & 02 & 40 \\
\hline $10-12$ Period & $\mathbf{0 2}$ & $\mathbf{4 0}$ & $\mathbf{0 1}$ & $\mathbf{2 0}$ \\
\hline $13-15$ Period & & - & - & - \\
\hline TOTAL & $\mathbf{0 5}$ & $\mathbf{1 0 0}$ & $\mathbf{0 5}$ & $\mathbf{1 0 0}$ \\
\hline
\end{tabular}

According to the table, $20 \%$ of respondents from the Methodist Secondary School and $40 \%$ of respondents from the Government Secondary School reported having 4-6 periods per week.

Also, $40 \%$ of respondents and $40 \%$ of respondents at the Methodist Secondary School and the Government Secondary School respectively reported that they have $7-9$ periods per week. Further still, the table indicates that $40 \%$ of respondents at the Methodist Secondary School have $10-12$ periods, while $20 \%$ of respondents at the Government Secondary School reported having 10-12 periods per week.

\section{Some Strategies to Combat the Constraints in English Language Teaching and Learning in Senior Secondary Schools} English is learned and taught everywhere because people have found out that knowledge of English is a passport for a better career, better pay, and advanced knowledge for communication with the entire world. There is an irony in the situation that English has been a part of our education system for more than a century, yet its teaching and learning is still enthroned by a myriad of problems. Below are some strategies that may help in English Language teaching and learning:

\subsection{Vocabulary checks}

This language teaching strategy used by most teachers tries to demonstrate a picture of the word. This helps to make the word easier for students to understand and remember. This strategy will help students connect new vocabulary with words they already know in their first Language (Brew Ster, Ellis and Girard 2004). Brew ster et al. (2004: 81) suggest that "providing examples of words, their meanings and demonstrating how they might be used when beginning to learn a language may be more important than attention to the grammatical components and spelling of vocabulary"

\subsection{Eliciting}

This strategy helps a teacher to bring forward students' ideas and extend and sustain discussion, which Fisher (2005) considers to be an important function of a teacher conversation that extend past a single exchange may help a learners language development as it could provide a more realistic model of how an authentic conversation occurs (Wells 1986)

\subsection{Modelling of Target Language}

Hill and Flynn (2006: 23) suggest that "Language structure and form should be learned in authentic contexts rather than through contrived drills in language workbooks". Therefore, the modelling of target language would seem to be an extremely important strategy for teachers to use, as these models may be a student's only guide on how the additional Language is used in a natural environment. 


\subsection{Think Alouds}

A think-aloud can be defined as the offering of a teacher's inner dialogue or opinions out loud for students to hear their thoughts, ideas and to model self-regulation of the thinking process, possibly through questions such as "what am I going to do now?" "What is my problem?", "I wonder what would happen if."

Fisher (2005: 47) suggests that the strategy of thinking aloud provides teachers with the opportunity "to model the world as we understand it in words". The use of such strategy may enable learners to hear more authentic and broader examples of the target language (Nunan 1991) and possibly help to scaffold and develop their even thinking skills (Fisher 2005)

\subsection{Error correction}

Hill and Flynn (2006: 32) suggest that "The best way to provide corrective feedback when grammar or pronunciation errors are made is simply to model the correct English without evenly calling attention to the error". Light bown and Spade (2006: 170) add that this corrective feedback should also be provided in a clear and precise way.

\subsection{Incorporating small Group and Pair work in lessons}

Students should be given opportunities to work in small groups and with a partner during lessons, which, according to Hill and Flynn (2006:55), maybe "a powerful tool for fostering language acquisition. "Research has shown that learners use considerably more language, and exploit a greater range of language functions when working in small groups" (Nunan 2000:51). Small groups also enable students to hear Language from each other, therefore a different source of input from the teacher. This might help to make students feel more comfortable and relaxed and possibly reduce the anxiety of attempting the target language (Hill and Flynn 2006).

\section{Conclusion}

Sierra Leone is facing a human resource problem, especially in the field of education. The manpower structure of the nation demands a large stock of well trained professional teachers for national development. In view of this situation, there should be purposeful training of the Secondary School teacher in order to impart; so she/he can, in turn, impart the acquired skills to the students to promote socio-economic development.

The teacher's perception of his/her capacity to promote learning is a critical component of student motivation. Efficacious teachers tend to persist with students, believing that the students can achieve, given enough differentiation of instructional strategies and teaching input.

Efficacious teachers are more likely to:

(a) Use praise rather than criticism.

(b) Persist with low-achieving students and be more accepting of them.

(c) Experiment with new curriculum and materials and

(d) Change instructional strategies directly impact student achievement resulting in higher student performance.

According to the responses in the set of questionnaires, it has been sufficiently corroborated that the teaching and learning of the English language are affected by a number of factors, most of which render the teaching of the subject less effective, thereby making the aim of teaching the English Language unrealistic.

According to the research, the factors that hinder the teaching/learning of the English language in Senior Secondary Schools can be summarized under the following broad categories:

a) The negative attitude of teachers and learners towards the teaching and learning of the subject

b) Lack of adequate teaching and learning materials.

c) Ineffective teaching approaches and methodologies.

d) Unconducive learning environment

e) Lack of special facilities for the teaching and learning of English Language such as libraries, internet facilities, reading materials, etc

f) Lack of opportunities for professional development

g) Limited exposition to the Language by students.

h) Lack of highly qualified and competent staff in the English Language

According to the research, the problems associated with the above factors have continued over the years and learners, and teachers have been managing to cope with them. It has so much become part of them that they no longer care to improve on them. This 
resigned attitude is certainly appalling for both teachers and learners alike. Something must be done at least in an attempt to resolve or alleviate those problems.

Teachers also indicated the poor academic background of students as one main factor affecting the teaching/learning of the English language in the two institutions.

Funding: The research received no extra funding.

Conflict of Interest: The authors hereby declare that there is no conflict of interest.

\section{References}

[1] Adrian, D. (1988) Teaching English: Trainer's Handbook. Cambridge

[2] Barr. S. (2012) Core Strategies to support English Language Learners. The Education Forum 76 (1) 105 - 117

[3] Bachman, L (1990) Fundamental Consideration in Language Testing. Oxford: Oxford University Press

[4] Bright J.A. (1991) Teaching English as a Second Language (6 ${ }^{\text {th }}$ Edition) London, Longman.

[5] Canale, M and Swain, M. (1980) Theoretical Bases of Communicative Approaches to Second Language Teaching and Testing in Applied Linguistics.

[6] Crystal, D. (1987) The Cambridge Encyclopedia of Language London, Cambridge University Press.

[7] Clancy, M \& Hruska, B. (2005) Developing Language Objectives for English Language_Learners.

[8] Cameron, L. (2001) Teaching Languages to Young Learners. Cambridge: Cambridge University Press.

[9] Domey, Z (2001) Motivational strategies in the Language Classroom ${ }_{L}$ Cambridge: Cambridge University Press.

[10] Elis, R \& Tomlison, B. (1980) Teaching Secondary English: A Guide to the Teaching of English as a Second Language. London: Longman Group Ltd.

[11] Mc Donough, S. (2002) Applied Linguistics in Language Education. Oxford University Press.

[12] Mc Giregov, G.P. (1991) Teaching English as a Second Language; Theory and Technique for_the Secondary Stage London, Longman.

[13] Nunan, D. (2000) Language Teaching Methodology Oxford: Phonix

[14] Freeborn, D. (1991) An Introduction to the Study of Language ${ }_{\llcorner}$Macmillan, London.

[15] Howatt, A. P. (1984) A History of English Language Teaching Oxford: Oxford University Press.

[16] Scott, W. A. \& Ytreberg, L. H. (1990) Teaching English to Children. Longman

[17] Stern, H.H. (1992) Issues and Options in Language Teaching. Oxford; Oxford University Press

[18] Savignon, S. (1997) Communicative Competence Theory and classroom practice

[19] Texts and contexts in Second Language Learning (2 ${ }^{\text {nd }}$ Edition), New York, MC Graw Hill

[20] Widdowson, H.G. (1990) Aspects of Language Teaching. Oxford: Oxford University Press. 